\title{
The Christian ideology of Dr Faustus
}

\section{Roma Gill}

Marie-Thérèse Jones-Davies (ed.)

\section{OpenEdition}

Electronic version

URL: http://journals.openedition.org/shakespeare/449

DOI: 10.4000/shakespeare.449

ISSN: 2271-6424

\section{Publisher}

Société Française Shakespeare

Printed version

Date of publication: 1 November 1981

Number of pages: $179-200$

ISBN: 2-86433-016-4

\section{Electronic reference}

Roma Gill, «The Christian ideology of Dr Faustus », Actes des congrès de la Société française

Shakespeare [Online], 3 | 1981, Online since 01 November 2007, connection on 21 January 2020. URL:

http://journals.openedition.org/shakespeare/449; DOI : 10.4000/shakespeare.449 


\title{
THEATRE ET IDEOLOGIES :
} Marlowe, Shakespeare

\author{
DIRECTEUR DE LA PUBLICATION \\ M.T. Jones - Davies
}

JEAN TOUZOT Libraire - Editeur

38 , rue Saint-Sulpice 75278 PARIS CEDEX 061982 
1982 Jean Touzot Libiaire-Editeur, Paris.

Reproduction et traduction mzme partielle interdite.

Tous droits réservts potir lous pays

y compris i'U,R.S.S. et les pays scandinaves

ISBN 2-86433-016-4 


\title{
AVANT-PROPOS
}

L'opposition soulignée par Horace entre éthique et esthétique Aut prodesse volunt aut delectare poetae - que les Elisabéthains aiment à évoquer, pourrait être le lien qui rattache les unes aux autres les communications, rencontres et table ronde de notre troisième congrès (1981) sur le thème : "Théátre et Idéologies: Marlowe, Shakespeare.» Toutefois, le résultat de nos échanges montre un dépassement possible de l'alternative éthique / esthétique, puisqu'il met en valeur l'insertion d'idéologies susceptibles de transformer la fonction même de la littérature.

Les pièces analysées dans le contexte de leur temps révèlent de multiples aspects de la vision du monde et de la place que l'homme $y$ occupe, tels que les projette le théâtre anglais au tournant du XVIe et au début du XVIIe siècle.

Une exploration du langage et de la pensée des deux grands dramaturges aboutit à un commentaire sur les courants philosophiques ou religieux, sur les idées parfois contradictoires et sur la curiosité intellectuelle jamais assouvie qui se font jour à travers la rhétorique de la scène et le jeu dramatique, du Faust de Marlowe à La Tempéte de Shakespeare.

\author{
M.T. jones-Davies
}

Présidente de la Société Française Shakespeare 
SOCIETE FRANCAISE SHAKESPEARE Actes de Congrès.1981

\section{THEATRE ET IDEOLOGIES : Marlowe, Shakespeare}

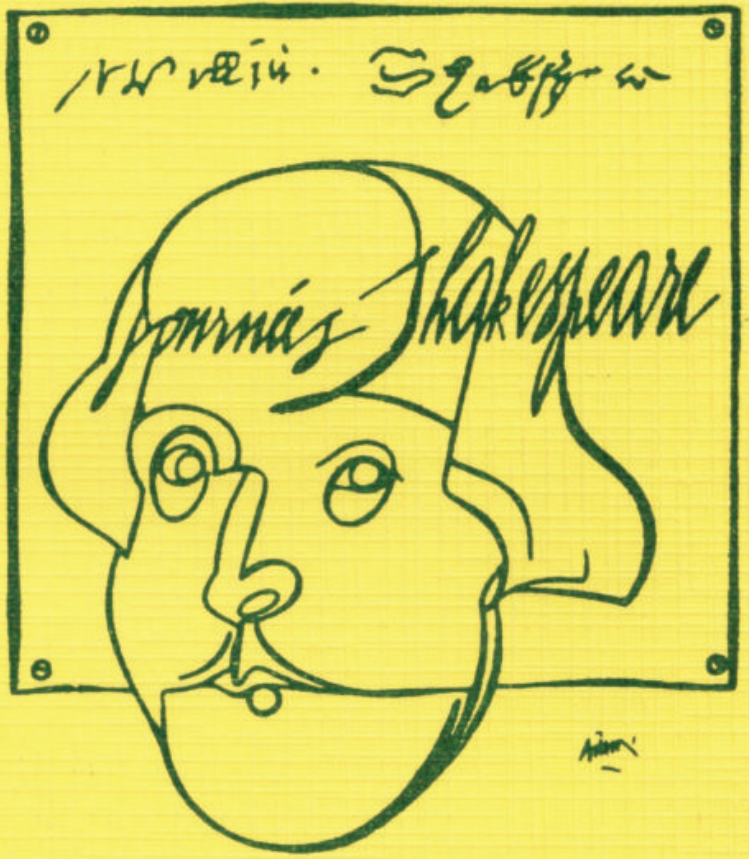

DIRECTEUR DE LA PUBLICATION M.T. Jones - Davies

JEAN TOUZOT Libraire - Editeur 38 , rue Saint-Sulpice 75278 PARIS CEDEX 061982 
Illustration de la couverture : affiche de Valerio Adami, spécialement conçue pour les Journées Shakespeare 1979 au Centre Georges Pompidou 


\section{TABLE DES MATIERES}

M.T. JONES-DAVIES Avant-propos

Théâtre et Idéologies: Marlowe, Shakespeare

S. TRUCHET

The Alchemy of Beauty: aesthetic principles in I Tamburlaine and their relationship to the hermetic ideology.

D. PRUDHOMME

L'idéologie du Juif de Malte et du Marchand de Venise.

D. GOY-BLANQUET

De Hall à Shakespeare : quelques glissements idéologiques opérés par la dramatisation dans Henry $I V$.

M.T. JONES-DAVIES Le Monıde du «si»: Idéologies Incertaines dans Comme il vous Plaira.

G. VENET

Temps et Idéologie : Marlowe, Shakespeare.

J. RICHER

Les Sept Caractères et les Quatre Tempéraments dans Jules César de Shakespeare.

F. LAROQUE

En marge de l'Idéologie : Antimasque et Grotesque dans le Dr Faustus et La Tempête.

A. LECERCLE-SWEET Conscience et Méconnaissance dans Edward The Second de Marlowe.

M.A. CONEJERO Shakespeare's Aesthe tic Scheme. (Extrait).

P.STEWART

Shylock, Shakespeare's Alien.

(Royal Shakespeare Company)

J.RUSSELL BROWN The Romantics' Shakespe are.

R. GILL

The Christian Ideology of Dr Faustus.

J. JACQUOT

Marlowe : de quelques problèmes d'interprétation. 
Rencontres entre Universitaires et Gens de Théâtre

Vendredi 4 décembre 1981
- Stuart Seide :Présentation du

Songe d'une nuit d'Eté. Mise en scène pour le Théâtre de Chaillot janvier 1982

- A propos d'Edouard (II) de

Bernard Turle

Bernard Turle : Métamorphoses de l'auteur et de l'écriture dramatiques. Intervention de Colin Harris (metteur en scène) 


\section{THE CHRISTIAN IDEOLOGY OF DR FAUSTUS}

In 1964, writing my first Introduction to an edition of Dr Faustus I quoted Leo Kirschbaum's assertion that «there is no more obvious Christian document in all Elizabethan drama» than this play. My misunderstanding of Dr Faustus was evidenced when I retorted that «Christianity has very few positives in this play ${ }^{1}$. In that New Mermaid edition both my text, and consequently my reading of the play were based on the 1616 Quarto - the version of Dr Faustus that has been most readily available (at least in England) since 1950. In some measure this explains my own incomprehension - and also (I would venture to suggest) the imperfect appreciation with wich Marlowe's play is to-day received by those who first encounter the tragedy in a modern edition. In the present paper I feel that before I can begin to comment on the ideology of Dr Faustus I must first attempt, briefly, to establish what I believe to be the text of the play.

Elizabethan drama abounds in textual problems, to the despair (and delight) of twentieth-century editors happily performing the function graphically described by A.E. Housman, who explained that

A textual critic engaged upon his business is not at all like Newton investigating the motions of the planets : he is much more like a dog hunting for fleas. ${ }^{2}$

With two early editions varying considerably from each other, Dr Faustus has many tender places that demand the modern editor's attention. The first edition, commonly known as the A Text, was published in 1604 , more than ten years after Marlowe's death. There were two further impressions (in 1609 and 1611) before a new edition, the B Text, appeared in 1616. Some of the differences between A and B are easily explained : the Act of Abuses, for instance, which became law in 1606, is responsible for the censorship which the B Text has suffered. Whereas the despairing Doctor of the A Text tries to evade imminent damnation with the cry of «O Ile leape vp to my God» (A 1462), ${ }^{3}$ the character in the B Text has to be content with a promise to «leape vp to 
heauen" (B 2048). Heavy-handed censorship (and not any doctrinal consideration) completely deprives the B Doctor of the final saving vision which is vouchsafed in the earlier text : «See see where Christs blood streames in the firmament" (A 1463). Such censorship problems are familiar to editors of Shakespeare : the Folio text of Othello (for example) betrays the origins of its copy manuscript - a censored prompt-book - in such details as Iago's trite observation that "heav'ns above all" and his mild oath «Heaven forbid» (II, iii. 96 and 253), both of which can be emended from Ql's readings of «God» for «Heaven».

Less easily detected are the difficulties that arise from the compositor's misreading or misunderstanding of his manuscript; and these continue to perplex Shakespeare's editors. Does Hamlet at I. ii. 129 lament his «too too solid flesh", using the Folio adjective; or is "sallied», the reading of all four Quartos, preferable ? And is this itself, as T.J.B. Spencer believes, a variant spelling of «sullied» which can be modernized as such ? ${ }^{4}$ Does Goneril complain (King Lear, IV, ii. 28) «My foot usurps my body» (Q1, uncorrected state), «A fool usurps my bed»(Q1, corrected state), «My foot usurps my head» (Q2), or "My fool usurps my body» (F) ${ }^{5}$ Dr Faustus has its share of such cruces. Does Faustus perform his conjuring under «the gloomy shadow of the earth" (A 244) or "the gloomy shadow of the night» (B 225)? Were the "thousand desprate maladies» really «cur'd by his medical skill (as in B 49) or merely (A 52) «easde»?

Such textual problems are, as I have indicated, fairly common in plays of the sixteenth and seventeenth centuries; and they are usually soluble by reference to a sound theory of the copy manuscript and its transmission to the printed text, the circumstances of writing and printing, and the editor's sine qua non - common sense. Even when the occasional wrong judgement is made - if the pleonastic sshadow of the night" is preferred to the scientific "shadow of the earth" (vouched for by Macrobius and La Primaudaye) - the effect is merely local, although of course many such errors will seriously affect the texture of the play. But Faustus B differs from Faustus A far more radically than the quartos of Hamlet or Lear differ from each other or from the Folio text. Faustus A and Faustus B present substantially 
different plays.

In 1602 Philip Henslowe, the theatrical impresario who held sole rights in most of Marlowe's plays, noted in his Diary the fact that he had

Lent vnto the companye the 22 of novmbz 1602

to paye vnto wm Bvrde \& Samwell Rowle

for ther adicyones in doctor fostes the some of

iiij ${ }^{1 i} 6$

There is nothing particularly strange about this entry (except perhaps Henslowe's highly idiosyncratic spelling). Bird and Rowley were competent hack dramatists whose names frequently appear in the Diary; and revision of sixteenth-century plays was often considered necessary to suit them to the tastes of seventeenth-century audiences (The Spanish Tragedy is a notorious case in point). But what were these «adicyones»? And what became of them ?

For more than three hundred years - until 1950 - it was generally and happily agreed that the contribution made by Bird and Rowley constituted the extra material to be found in the B Text of 1616 , a reprint of which in 1619 bore on its title page the advertisement that there were «new Additions». In 1950 however, Sir Walter Greg published his monumental Parallel Texts edition of Dr Faustus, arguing in the Introduction that B's additional matter was in fact part of the original play. His evidence was drawn from supposed echoes of, or allusions to, the disputed matter in plays which could be said to pre-date the 1602 entry in Henslowe's Diary. He explained their absence from A Text by presupposing (with Leo Kirschbaum) ${ }^{7}$ that A was by nature a «Bad Quarto», the memorial reconstruction of a performance of the play - from which B's additional scenes had been neatly excised - illegitimately published by one or more of the members of the acting company. Recently Greg's arguments have come under scrutiny and found to be fallacious, but as yet no editor has seen fit to discard B's additions. Fredson Bowers, in his Complete Works of Marlowe (1974), thought the question unimportant, believing that

No trustworthy evidence suggests that the B-text revisions concerned themselves in any significant part to alter Marlowe's contributions to the play.

(ii. 143) 
His edition of Dr Faustus, consequently, is much the same as all the other versions of the play, whether in old or new spelling, which have proliferated since 1950; and, like them, it gives what I believe to be a misleading impression indeed, a travesty - of Marlowe's last and most famous work.

Most of the B Text «adicyones» are trivial - expansions of the comedy at the papal banquet, the court of the German emperor, and the dislocated tavern scene.Only one, comprising the larger part of Act V scene ii in modern editions, significantly affects Marlowe's composition.

B's scene opens with the ascent of Lucifer, Belzebub and Mephostophilis, who announce their arrival «from infernal Dis» to take a voyeuristic delight in the protagonist's final anguished hour. This calls for a more sophisticated staging (perhaps a balcony) than A requires; and the presence of spectators must distract the audience's attention from the victim at a time when the painfully disjointed prose in which the two Texts coincide insists upon sympathy. The shift of mood and mode is cruel, but has little ideological implication.

After Faustus's confession to the Scholars, B's Good and Evil Angels make their final appearances, respectively reproaching and gloating. A's Angels remain after the signing of the infernal pact only long enough to pronounce the doctrine of repentance; they depart at A 710, with the Good Angel (unusually) having the last word:

\section{Enter good Angell and euill}

euill $A$. Too late.

$\operatorname{good} A$. Neuer too late, if Faustus can repent.

euill $A$. If thou repent diuels shall teare thee in peeces.

$\operatorname{good} A$. Repent,\& they shal neuer race thy skin. Exeunt.

They perform the same function, at the same point of the play, in B, and seem likewise to have been forgotten - or to be no longer necessary. But the Act $\mathrm{V}$ «adicyone" allows for a further appearance, which again asks for fairly sophisticated staging in its melodrama. The stage-direction at B 2005 (surely originating in the theatre) calls for «Musicke while the Throne descends", and the Good Angel points out to Faustus what he has lost :

Faustus behold

In what resplendant glory thou hadst set 
In yonder throne, like those bright shining Saints, And triumpht ouer hell.

B 2011-4

His last line prepares for the standard medieval image of hell : "The iawes of hell are open to receiue thee» : doubtless what was revealed with the stage-direction "Hell is discourered» (B 2016) was the familiar «j Hell mought» which apparently belonged to the Admiral's Men in $1598^{8}$. The Bad Angel proceeds to remark Pinteresque kitchen detail :

There are the Furies tossing damned soules,

On burning forkes: their bodies broyle in lead.

There are liue quarters broyling on the coles

Such a «popular» concept of hell - localized, and expressed in physical terms - need not be incompatible with the abstract state described by Mephostophilis early in the play when he certified that he himself was aiways and everywhere in heil :

Why this is hel, nor am I out of it :

Thinkst thou that I who saw the face of God,

And tasted the eternal ioyes of heauen,

Am not tormented with ten thousand hels.

in being depriv'd of euerlasting blisse.

(A 321-5)

This account of the torment of deprivation is not by any means peculiar to Marlowe; the words of the play here almost translate those of St. John Chrysostom; «si decem mille gehennas quis dixerit, nihil tale est quale ab illa beata visione excidere» ${ }^{9}$. And precedent for the combination of place and state of torment can easily be found - in, for instance, Caxton's Mirrour of the World (1480), where hell is geographically placed «in the most lowest place, most derke, and most vyle of the earthe», but where the sufferings of the damned are explained in terms of the mental pain of a man

that had a grete maladye, so moche that he shold deye, and that he were brought in to a fair place and pleasaunt for to have Joye and solace; of so moche shold he be more hevy and sorowful.

I would simply record my personal preference (so to speak) for the bleakness of the ubiquitous hell described by Mephostophilis - a description which is, incidentally, given 
additional strength for me by the account of a twentiethcentury Mephostophilis-the deuteragonist of D.J. Enright's Faust Book (1979); here the devil answers his Doctor's embarrassing question with the confession that

Well, it's empty. hell is,

Oh there are crowds of people all around. But hell, you feel, is - empty.

The word is emptiness.

Enright's Faust Book is a sequence of non-dramatic lyrics; and obviously Bird and Rowley's «adicyone»would make for a thrilling moment to excite the groundlings and gratify their imputed tastes for dumb shows and noise. There is, then, theatrical justification for its inclusion - and, once again (as with the appearance of the infernal trinity) the passage has little ideological implication for the rest of the play.

But there are some lines in this Act V expansion that cannot be included in the general justification of the passage on grounds of theatrical effectiveness and ideological insignificance : the eleven lines (B 1983-1994) in which the Doctor confronts his familiar and endeavours to shift the blame on to the spirit :

$\mathrm{O}$ thou bewitching fiend, twas thy temptation, Hath rob'd me of eternall happinesse.

(B 1986-7)

The «bewitching fiend» is triumphant, and relieves Faustus of all responsibility :

I doe confesse it Faustus, and reioyce;

Twas I, that when thou wer't $i$ the way to heauen

Damb'd vp thy passage, when thou took'st the booke.

To view the Scriptures, then I turn'd the leaues And led thine eye.

(B1988-92)

Philip Brockbank, accepting B's additional material as part of Marlowe's original intention, reacted to these lines as «A terrifying speech, recoiling upon our whole experience of the play»; ${ }^{10}$ and it seemed to me in 1965 that "The whole nature of the play is changed by this addition [B 1983 -1994]». " I hold that opinion even more strongly today. These eleven lines, which have no bibliographical authority, 
change a magnificent tragedy into a cynical Morality Play, reducing its unique, intelligent, and responsible protagonist to a mere puppet, and subverting the essentially Christian ideology of a play whose author was popularly supposed to be "Not inferior to any ... in Atheisme and impietie»!2

The first soliloquy is a superb achievement; it both tolerates and demands frequent examination. The play opens in a manner comparable to that of The Jew of Malta : there is an expository speech by a "Chorus" figure, and then the protagonist is "discovered", engaged in a characteristic activity (Barabas counts his shekels and Faustus sums up his learning). It would seem that Marlowe is making use of that part of the public theatre's acting-area so puzzling to modern critics, the "inner stage» which could be masked by curtains and then suddenly revealed with the stage-directions.

Enter Barabas in his Counting-house, with heapes of gold before him

and

\section{Enter laustus in his Study}

I think that this is particularly important in Dr Faustus not because it shows Marlowe's familiarity with the physical conditions of his theatre, but because it creates an impression of continuousness. The soliloquy itself is some sixty lines long, but it represents the thought-processes of years. Faustus does not act on the spur of the moment: he has spent a lifetime (almost) mastering and evaluating the different subjects, turning to medecine when logic failed to satisfy, and to law when the physician's art disappointed him.

In this opening speech Marlowe establishes Faustus as a man of learning and experience whose name does not sound incongruous in the impressive roll-call of Aristotle, Galen, Justinian and Jerome, with whom he shares a lingua franca. The Latin quotations form, of course, the chiet means whereby Faustus's authority is established. The fact that they are not always accurate is unimportant : this is a play, not a doctoral dissertation, and only a modern editor (or student with his annotated edition) is likely to observe that "Aristotles workes" did not provide the formulation "Bene disserere est finis logicis» (A 35, 37). ${ }^{13}$ Theatre audienas were more likely to respect the Latin than question the attribution. 
Marlowe seems to demand a more critical reaction from his audience at the point when, having dismissed the whole of the Cambridge secular curriculum, Faustus turns to theology : "when all is done, Diuinitie is best" (A 67). He claims to quote from «Ieromes Bible»: "Si peccasse negamus, fallimur, \& nulla est in nobis veritas» (A 71); and, as usual, the Latin is followed by an English version :

If we say that we have no sinne,

We deceiue our selues, and theres no truth in vs.

(A 72-3)

The Latin, however, is not that of the Vulgate: Marlowe is ascribing to "Ieromes Bible" his own translation of a remembered sentence, which originates in the First Epistle General of John (chapter 1, verse 8). Here it is possible to remark a dramatic irony, readily appreciated by those whose memories can supply the next verse from the Epistle - which would have solved the doctor's dilemma :

If we confess our sins, he is faithful and just to forgive us our sins, and to cleanse us from all unrighteousness.

But Faustus's English quotation does not, in fact, come directly from the Bible : the words he uses (quoting accurately) are those of the 1559 Book of Common Prayer where they are separated from the consolation of the Epistle's verse 9, being used to preface the exhortation to repentance which, with the order for General Confession, immediately follows. If The Book of Common Prayer is recognised as the immediate source for this sentence, there is the risk of some diminution in the dramatic irony, since this arises largely from the context supplied by the Bible. On the other hand, it redeems Faustus from the charge of impetuousness and inaccuracy in this most serious matter.

The prayer Book sentence forms the minor premise in the syllogism whose major premise has already been stated, with horror and awe (evident in the exclamation and repetition) :

Stipendium peccati mors est : ha, Stipendium, \&c. The reward of sinne is death : thats hard.(A69-70)

Formulated in these terms, the syllogism is capable of only one solution, and the scholar "that was wont to make [Wittenberg] schooles ring with, sic probos (A 201-2) 
demonstrates his mastery of logic :

Why then belike we must sinne,

And so consequently die. (A 74-5)

The whole soliloquy has been driving, powerfully and inexorably, to this moment when Faustus experiences the ultimate frustration of all earthly ambition. It is comparable to the last scene of Tamburlaine Part II, where the shepherdwarrior, having called for a map, proudly indicates the extent of his conquests-all the time interspersing his boasts with the despairing lament "And shall I die, and this unconquered» (V. iii. 150). Tamburlaine's frustration is final, but Faustus, having decided that he "must die an euerlasting death» (A 76), seeks to evade his predicament by turning to magic, hoping - through the acquisition of new skills to achieve a «dominion» which «Stretcheth as farre as doth the minde of man» (A 90-91).

There is a terrible irony here. Faustus has just demonstrated - superbly - the power of the human mind, which can wrestle with the complexities of logic and law and understand the workings of the human body. And at the same time he has demonstrated, even more powerfully, the limitations of man's understanding.

As I said above, this first soliloquy rewards frequent examination; but my discussion has not been simply selfindulgence. I want to stress the individuality of Marlowe's protagonist. Dr Faustus is given not only a local habitation and a name, but parents ("base of stocke», A 12) and a curriculum vitae which even includes publications (the «billes hung vp as monuments», A 50). Most important of all for our understanding of this unique personality is the exhibition provided in the soliloquy of an independent mind, actively engaged in an attempt to understand some of the fundamental problems of human existence. This is no "Everyman» figure, the prototype of humanum genus who is the hero common to all the medieval Morality Plays. Dr Faustus, like Coriolanus (and all other heroes of tragedy) «is himself alone» (Coriolanus, I, iv. 51).

The conjuration scene does nothing to destroy this impression of Faustus as a man of powerful intellect and personal charisma. He has acquired a new skill, and he delights in its use (although those familiar with techniques of diabolical invocation might note a characteristic careless- 
ness when Faustus forgets to specify the form that the spirit should assume - an omission that Marlowe uses to good theatrical effect : the stage-direction that follows the conjuration is simply (in both Texts) "Enter a Diuell», but B's copy - which I believe to be prompt-book - supplied the English word «Dragon» in the middle of the Latin formula (B 246). This I interpret as an anticipatory direction, warning the property-master to be ready with the appropriate monster : the properties of the Admiral's Men included «j dragon in fostes» ${ }^{14}$, and the title-pages of the B quarto depict Faustus standing within his circle, book in hand, contemplating a creature with wings and tail that seems to have risen through the floor.

Marlowe shows remarkable skill in manipulating the mood of this scene from the melodrama of the opening, where Faustus must first conjure up the impression of darkness and night which.

Leapes from th'antarctike world in to the skie,

And dimmes the welkin with her pitchy breath.

(A 246-7)

This prepares for the invocation of the devil (which even in 1982 is awesome in its Latin sonority) and the appearance of the devil-dragon; then the horror is dispelled with a joke - and Faustus incidentally affirms his Protestant sympathies as he instructs the apparition to

Goe and returne an old Franciscan Frier,

That holy shape becomes a diuell best (A 269-70) Between the appearance of the "Dragon" and the entrance of Mephostophilis the audience has time to calm down, whilst a slightly hysterical Faustus congratulates himself on the efficacy of his conjuring.

The first discussion with Mephostophilis is - or should be - a very sobering experience. The unhappy devil speaks with a bleak infinity of misery and experience to the uncomprehending doctor who is exuberant, over-confident, and so ignorant that he can offer to instruct his mentor: "Learne thou of Faustus manly fortitude, And scorne those ioyes thou neuer shalt possesse" (A 330-31). The perfect description of his conduct here is in Isabella's words to Angelo when she describes how.

man, proud man,

Dress'd in a little brief authority, 
Most ignorant of what he's most assur'd

His glassy essence - like an angry ape

Plays such fantastic tricks before high heaven

As makes the angels weep.

(Measure for Measure, II. ii. 118-123)

The intellectual tricks that Faustus plays as «he confounds hell in Elizium» (A 304) almost make the devil weep as he cries

O Faustus, leaue these friuolous demaunds, which strike a terror to my fainting soule.

(A 326-7)

This is the devil's own cry of despair when he recognises that the simple truths with which he has answered Faustus's questions about Lucitier, the fallen angels, and the reality of eternal damnation have had no effect on the doctor's resolution. The unexpectedly emotional appeal surprises even Faustus, but provokes only a sardonic comment What, is great Mephastophilis so passionate, For being deprivd of the ioyes of heauen ?

(A 328-9)

His determination now seems far stronger than it was at the beginning of the scene when, despite the excitement with which he embarked on his new experiment, he was forced to reassure himself : "feare not Faustus, but be resolute» (A 257). The scene ends with his delighted "speculation" (A 358) as he waits for the midnight assignation and the exchange of contracts.

Ideologically this scene's significance lies in its demonstration that Faustus is in full possession of all the facts : he has been cautioned about the consequences that will ensue if he persists in his chosen action, and urged by Mephostophilis (surely the most powerful devil's advocate) to restrain his folly. He can now make no appeal on grounds of ignorance. There are, however, still more warnings to come. His conscience speaks, when he acknowledges that «something soundeth in mine eares" persuading him to relinquish his new-found skills and "turne to God againe» (A 444-5); and even his own body revolts, withholding the blood that must write the contract. Faustus perceives the omen with dazzling clarity :

What might the staying of my bloud portend ? Is it vnwilling I should write this bill ? 
Why streames it not, that I may write afresh ? Faustus giues to thee his soule : ah the re it stayde, Why shouldst thou not? is not thy soule thine owne ? (A 504-8)

The tension mounts as Faustus, insisting on the freedom to possess his own soul, instantly commits it to Lucifer with the self-conscious "Consummatum est", the last words of Christ on the cross (St John, 19:30). A final warning comes when he hallucinates the "inscription» on his arm : "llomo fuge» (A 518), and then the atmosphere relaxes when Mephostophilis offers distraction - «lle fetch him somewhat to delight his minde» (A 523) - with the dancing devils, "giuing crownes and rich apparell to Faustus" (A $525 s d$ ).

The relaxed interlude is a necessary preparation for the intense solemnity of the episode that follows, in which verse gives way to prose for the official exchange of contracts between Faustus and Mephostophilis (acting as agent for Lucifer). When all the conditions have been iterated, the legalistic devil asks the formal question «Speake Faustus, do you deliuer this as your deede ?" (A 558). I suggest that here "deede" has more than the superficial sense of $O E D 4$ : «an instrument in writing, purporting to effect some legal disposition»; it has rather the import of $O E D$ 1: "That which is done, acted, or performed by an intelligent or responsible agent $»$. The italics are mine.

The first soliloquy insists upon the intelligence of Faustus, and the scenes that follow emphasise his responsibility. His response to Mephostophilis' question about the "deede», though apparently flippant, seals his damnation : «I [Aye], take it, and the diuell giue thee good on't (A559).

The middle parts of the play are of doubtful authorship; nevertheless they present dramatically a classic case of mental and spiritual deterioration, the symptoms of which are prosaically described by William Perkins in his Discourse of the Damned Art of Witchcraft (published 1608) :

When they first beginne to grow in confederacie with the deuill, they are sober, and their understanding sound, they make their match waking, and as they think wisely enough, knowing both what they promise the deuill, and vpon what con- 
ditions, and therefore all this while it is no delusion. But after they be once in the league, and haue been intangled in compact with the deuill (considerately as they thinke, for their owne good and aduantage) the case may be otherwise. For then reason and vnderstanding may be depraued, memorie weakened and all the powers of their soule blemished. Thus becoming his vassals they are deluded, and so intoxicated by him that they will run into thousands of fantastical imaginations, holding themselues to be transformed into the shapes of other creatures, to be transported into the ayre into other countries, yes, to do so many strange things which in truth they do not. ${ }^{15}$

Perkins, who died in 1602, could almost be reporting a performance of Dr Faustus; but I think it unlikely that so Calvinistic a theologian would have had much time for the theatre. Certainly he would not have derived his doctrine from a play.

The first item of the infernal contract declares Faustus's damnation to the orthodox Christian : «that Faustus may be a spirit in form and substance" (A 541). For the Elizabethans «spirit» had a variety of meanings when, for instance, Valdes and Cornelius speak of «spirits" it would appear that they are referring to Paracelsian elemental daemons (in the A Text Valdes calls them "the subiects of euery element" - A 155; B's editor clarifies when he emends "subiects» to "spirits»- B 144). But the stage-direction at B95, "Enter the Angell and Spirit". clearly uses the word as a synonym : A's direction at the same point reads «Enter the good Angell and the euil Angell». When Faustus, struck with remorse after he has signed the contract, is told by the Evil Angel «Thou art a spirite, God cannot pitty thee" (A 642), there is no doubt that «spirite» is synonymous with «devil»: Faustus must now be identified with the fallen angels whom Mephostophilis had earlier described as

Vnhappy spirits that fell with Lucifer. Conspir'd against our God with Lucifer.

And are for euer damnd with Lucifer. (A 315-7)

Medieval theology was quite clear about the fate of the fallen angels : they were eternally damned, and could never achieve salvation. Renaissance theologians continued the 
doctrine - as we can see from John Donne's explanation that

To those that fell, can appertain no reconciliation; no more then to those that die in their sins; for Quod homini mors, Angelis casus; The fall of the Angels wrought upon them, as the death of a man does upon him. ${ }^{16}$

The play can only continue because the audience cannot be sure (just as Faustus himself cannot be sure) how absolute is the signing of the contract, and the Good Angel's reminder, which follows Faustus's first disappointment with infernal resources, ensures that the conflict in Faustus's mind (and consequently the tension in the play) continues to the end :

Faustus, repent, yet God will pitty thee. (A 641) Faustus himself acknowledges the truth of this reminder :

I [Aye] God will pitty me, if I repent. (A 645)

But the Evil Angel, as usual, has the last word:

I [Aye] but Faustus neuer shal repent; (A 646) and Faustus is forced to acknowledge this truth, too :

My hearts so hardned I cannot repent. (A 647) Then follows his confession of despair - a «deepe dispaire» that tempts to suicide, but which is overcome with "sweete pleasure» (A 654).

Shortly after this point Marlowe seems to have lost interest (temporarily) in his play; perhaps the triviality of the central section of his source narrative. The English Faustbook, bored him - or perhaps the problems of displaying superhuman knowledge (understandably) defeated him. But the audience must be entertained, and there must also be the impression that time (the contracted four and twenty years) is passing. Marlowe takes up the writing again at Act V, although for the first few lines he seems a little unsure of himself.

For the benefit of his academic friends he conjures up the famous Helen of Troy, "the admirablest Lady that euer liued" (A 1280). When they see the apparition, the Scholars are speechless; they can only gasp with wonder

Too simple is my wit to tell her praise,

Whom all the world admires for maiestie.

(A 1291-2)

Helen is a remarkably ambivalent figure - and not just in 
Marlowe's play. Her combination of absolute beauty and destructive potential was remarked by the Trojan Elders in the Iliad when Helen passed them as they sat, too old to join in the fighting, on one of the city towers, «like cicadas perched on a tree in the woods, chirping delightfully».

When they saw Helen coming to the tower they lowered their voices,

"Who on earth», they asked one another could, blame the Trojan and Achaean men-at-arms for suffering so long for such a woman's sake ? Indeed, she is the very image of an immortel goddess. All the same, and lovely as she is, let her sail home and not stay here to vex us and our children after us. ${ }^{17}$

In Shakespeare's Troilus and Cressida Helen is the focus for argument amongst the Trojans and the Greeks; at one moment she is praised as "a theme of honour and renown, A spur to valiant and magnanimous deeds»(II. ii. 199-200); and later it is pointed out that

For every false drop in her bawdy veins

A Grecian's life hath sunk; for every scruple

Of her contaminated carrion weight

A Troyan hath been slain. (IV. i. 71-4)

Marlowe is well aware of this ambivalence - as we appreciate with Helen's second appearance, after the Scholars have departed.

The apparition is not, of course, Helen herself; and I think it is very important to remind ourselves of exactly what it is. Faustus has done this kind of conjuring before, when he produced Alexander the Great and his paramour at the request of the Emperor of Germany. On that occasion he prepared the spectators for the exhibition by explaining the nature of the illusion, admitting that

it is not in my abilitie to present before your eyes, the true substantiall bodies of those two deceased princes which long since are consumed to dust. (A 1081-3)

He could, however, promise that

such spirites as can liuely resemble Alexander and his Paramour shall appeare before your Grace, in that manner that they best liu'd in, in their most florishing estate. (A 1086-8) 
The scene is almost certainly not Marlowe's own work, but the reminder is still useful, and so too is the warning that was added by the revisers in the B Text who told the Emperor not to address the apparitions, «But in dumbe silence let them come and goe» (B 1285). Similarly Faustus warns the Scholars that when they see «that pearlesse dame of Greece» they should «Be silent ... for danger is in words» (A 1290).

The first appearance of Helen must be exciting (and it certainly offers an enormous challenge to a twentieth-century director of Dr Faustus); but the audience should have recovered from its excitement by the time that the spirit is recalled, this time by Faustus himself with the expressed intent that her

sweete imbracings may extinguish clea[ $r] \mathrm{e}$

Those thoughts that do disswade me from my vow, And keepe mine oath I made to Lucifer.

(A 1352-4)

The solemnity of her entrance in the early performances of the play can be inferred from the stage-directions. Both Texts ask for "Musicke» when she is presented to the Scholars, and both state that she "passeth ouer the Stage» (A 1291) - which, it has been suggested ${ }^{18}$, means that the character moves from one side of the yard, across the stage, and out at the other side of the yard, instead of entering by the stage doors. This would, of course, prolong the magic moment, which is received with the famous apostrophe to "the face that la[ uIncht a thousand shippes» (A 1357ff.). The speech balances the two opposed concepts of beauty and destruction, culminating in the irony of the conceit

Brighter art thou then flaming lupiter.

when he appeard to haplesse Semele. (A 1373-4)

Faustus forgets his warning to the Scholars, not only speaking to Helen but also, and most dangerously, embracing her. Like any sixteenth-century lover, he plays with the neoPlatonic notion that a lover's soul could be drawn out of his body on recognition of the beloved. In Dido Queene of Carthage, for instance. Dido's rapture finds such expression when she hears Aeneas's confession of love :

What more then Delian musicke doe I heare,

That calles my soule from forth his liuing seate.

(III. iv. 52-3) 
Faustus's rapture is as great - but his intended conceit is no metaphor,it is an ironic reality:

Sweete Ilelen, make me immortall with a kisse :

Her lips suckes forth my soule, see where it flies.

(A 1359-60)

I share Greg's view ${ }^{19}$ that the kiss is a token act of intercourse: when Faustus leaves the stage in company with Helen, promising her that unone but thou shalt be my paramour» (A 1376) he is guilty of the sin of demoniality, and totally possessed by the devil. What one of the Scholars believed to be the "onely Paragon of excellence» (A 1297) has become a succuba.

The A Text certainly insists that this episode is of major significance in the damnation of Faustus. An entrance is marked for the Old Man at A 1363, immediately following the kiss. The Old Man's first appearance ( at A 130I) showed him to be some kind of emissary from Heaven, and a type of the true Christian. Although the verse is unusually bad, his speech has a powerful effect on Faustus, almost persuading him to repent and offering a vision of comfort:

I see an Angell houers ore thy head.

And with a violl full of precious grace,

Offers to powre the same into thy soule. (A 1320-22)

But what the Old Man witnesses in Faustus's courting of Helen is enough to make him give up hope :

Accursed Faustus, miserable man,

That from thy soul excludst the grace of heauen,

And fliest the throne of his tribunall seate.

(A 1377-9)

His meditation is interrupted by the tormenting devils. and his steadfast endurance of the physical suffering will serve later as a contrast to Faustus's inherent cowardice.

The B Text omits this second appearance of the Old Man, and consequently loses the accurate diagnosis of the doctor's dilemma expressed in the Old Man's recognition that Faustus has closed his soul to "the grace of heauen". For a Christian this explains Faustus's lament, much earlier in the play, that "My hearts so hardned 1 cannot repent" (A 647). The situation which Faustus describes as he takes leave of the Scholars can be summarized in the words of the Man of Despair, shut up in an iron cage, in Bunyan's 
Pilgrim's Progress:

I have grieved the Spirit, and he is gone; I tempted the Devil, and he is come to me; I have provoked God to Anger, and he has left me; I have so hardened my heart that I cannot repent. ${ }^{20}$

When the Scholars recommend that he should "call on God», they learn of the condition of despair in which Faustus has increasingly found himself; ever since he signed the infernal contract he has been unable either to weep or to pray :

I would weepe, but the diuel drawes in my teares, gush foorth bloud, insteade of teares, yea life and soule, Oh he stayes my tong, I would lift vp my hands, but see, they hold them, they hold them. (A 1416-20)

The disjointed prose has more eloquence, in this context, than Marlowe's powerful verse : its formlessness speaks the disorder of Faustus's emotions. He is in an intolerable situation, but one that is not unfamiliar to Christian thinkers. John Donne expressed the dilemma in the second of his "Holy Sonnets» although the ease with which the sonnet resolves itself suggests that Donne's experience did not trouble him greatly :

Yet grace, if thou repent, thou canst not lacke:

But who shall giue thee that grace to beginne?

Faustus can never find the "grace to beginne»; his spasmodic efforts at repentance cannot withstand the devil's threats : "the diuell threatned to teare me in peeces, if 1 namde God» (A 1431-2).

Faustus's condition can only properly be understood in terms of contemporary Christian doctrine. He has committed the one sin for which there is no forgiveness - the sin against the Holy Ghost. St Matthew's Gospel records Christ's teaching on the subject (in chapter 12, verses 31 and 32):

I say unto you. All manner of sin and blasphemy shall be forgiven unto men : but blasphemy against the Holy Ghost shall not be forgiven unto men.

And whosoever speaketh a word against the Son of Man, it shall be forgiven him : but whosoever speaketh against the Holy Ghost, it shall not be forgiven him, neither in this world, neither in the world to cone. 
The precise nature of the sin against the Holy Ghost is not defined in any of the Gospels, but Renaissance theologians followed the early Church Fathers in their teaching that pride and despair - two apparent opposites working in conjunction - could be so called. The «Schoolemen», explained Donne, have noted certain sins

which they have called sins against the Holy Ghost, because naturally they shut out those meanes by which the Holy Ghost might work upon us. The first couple is, presumption and desperation; for presumption takes away the feare of God, and desperation the love of God ... And truly ... To presume upon God, that God cannot damme me eternally in the next world, for a few a hall-houres in this ... Or to despair, that God will not save me ... al these are

shrewd and slippery approaches towards the sin against the Holy Ghost. ${ }^{21}$

The pride of Dr Faustus is evident from the very beginning of the play; even before the action starts, the Prologue has described him as being "swolne with cunning of a seife conceit» (A 21), and invoked Icarus as the type of uncontrolled ambition whose destruction Faustus must share, just as he shares the aspiration. And despair is present in his mind even before the contract is drawn up: meditating in his study before the appointment with Mephostophilis, he asks

Now Faustus must thou needes be damnd

And canst thou not be saued? (A 438-9)

His decision then was to "Despaire in God» (A 442); and during the course of the play despair increases as pride grows less.

The sixteenth-century theologian Augustine Marlorat emphasised another quality which seems to have been, for him, a sine qua non for the committing of this sin: the sinner must know what he is doing. According to Marlorat, when man is so touched with the light of the troth that he cannot pretend ignorance, and neuertheless of determinate malice resisteth, then he sinneth against the holy Ghost, and it is not possible for him to be renued by repentance, in that he hath forsaken God. ${ }^{22}$ 
Marlowe's Dr Faustus «cannot pretend ignorance» - unless the B Text addition in Act V is allowed to take responsibility away from him, robbing him also of his individuality and tragic stature.

My title, "The Christian Ideology of Dr Faustus». seems to suggest a coherent system of thought supporting the play, but I do not claim this as the case: Dr Faustus is not a drame à thèse. But I would certainly insist that Marlowe's last (and probably unfinished) play should be read - to return to Kirschbaum's phrase - as a "Christian document»,. It is a tragedy which (purged of the B Text «adicyones») answers the question posed in the Gospel According to St Mark (8:36): "what shall it profit a man, if he shall gain the whole world, and lose his own soul ?"

Roma GILL 


\section{NOTES}

1. Dr Faustus, ed. Roma Gill, published in the New Mermaid Series (1965), p. xxvii. Kirschbaum's statement was made in his essay «Marlowe's Faust us : A Reconsideration», Review of English Studies XIX (1943), pp. $229 \mathrm{ff}$

2. The Application of Thought to Textual Criticism», published in A.E. Housman . Selected Prose, ed, John Carter (1961), p. 132.

3. Quotations from Dr Faustus are taken from the Parallel Texts edition of W.W. Greg $(1950 ; 2$ nd impression 1968); the prefix A or B to the line number indicates whether the reading is that of the 1604 (A) or 1616 (B) quarto. Quotations from Marlowe's other plays are taken from The Complete Works of Christopher Marlowe, ed. Fredson Bowers (1974).

4. See his edition of Hamlet (1981).

5. This problem is discussed by Thomas (layton in his essay "Old Light on the Text of King lear,. Modern Philology Vol. 78 (1981), pp. 347ff ए. 206.

6 Henslowe's Diary, ed. R.A. Foakes and R.T. Kickert (1961),

7. The Good and Bad Quartos of Dr Faustusv, by 1 eo Kirschbaum, The lihrary $\mathrm{V} n \mathrm{X}$ XVI $(1945-6)$, pp. $272 \mathrm{ff}$.

8. Henslowe's Diary. p. 319

9. This was first pointed out by John Searie in The Times I iterary Supplement (15 Fehruary 1936).

10. Marlowe: "Dr Faustus», by J.P. Brockbank (1962), p. 55.

11. New Mermaid eđition. p. xviii.

12. Thomas Beard, The Thearre of God's Judgements (1597), p. 149.

13. The definition is from the Dialecticae of Petrus Ramus (15 15-72).

14. Henslowe's Diary, p. 320.

15. My quotation is taken from the anthology In God's Name, compiled by John Chandos (1971), p. 132.

16. From a sermon «Preached at St Paul's, upon Christmas Day.1622。 The Sermons of John Donne, ed. G.R. Potter and E.M. Simpson (1959), Volume IV, p. 299. $(1950)$

17. The Iliad, Book III; I quote from the translation of F.V.Rieu

18. See Aliardyce Nicoll, "Passing over the Stage», Shakespeare Survey XII (I959), pp. $47 \mathrm{ff}$.

19. See W.W. Greg, "The Damnation of Faustus", Modern l.anguage 
Review (1946); reprinted in «Dr Faustuss: a Casebook, ed. John Jump (1969) pp. $71 \mathrm{ff}$.

20. Part the First; my quotation is from an edition of 1882 , p. 32 .

21. From a sermon «Preached upon Whitsunday.? 1623», The Sermons of John Donne, Volume V, pp. 93-4.

22. A treatise of the sin against the holy ghost (?1570), f. Aiv ${ }^{\mathrm{r}}$. 